\title{
FOUR NEW SPECIES OF CHIRONOMID $\&$ FROM THE GREATER ANTILLES
}

\author{
BY BERTRAM I. GERRY, \\ Department of Agriculture, Boston, Mass.
}

The material, from which the new Cuban species were isolated, was collected by Professor Nathan Banks of the Museum of Comparative Zoology of Harvard University. That from which the new Jamaica species were taken, was collected by Mr. W. S. Brooks of the same institution. The types may be found in the collection at the Museum mentioned above.

Bezzia banksi sp. nov.

Female.-Dull brown. Head brown, vertex grayish, eyes narrowly separated dorsally, antennæ pale brown. Thorax dull brown, pronotal lobes silvered dorsally, mesonotum dull brown, sparsely clothed with short golden hairs, a grayish pollinosity extending over the lateral portions of the disc and the upper portions of the pleurae, scutellum yellowish, halters whitish. Abdomen blackish brown, sparsely clothed with short golden hairs, the ground color somewhat obscured by the conspicuous grayish pollinosity, venter fulvous. Legs blackish brown, fore femora with six apical spines grouped five and one, mid and hind femora each possessing three apical spines; tarsi yellowish, first, second, third and fourth segments narrowly blackened at apices, the fifth entirely black; metatarsi of fore and mid legs equal to the combined length of second, third, and fourth tarsal segments, those of the hind legs equal to the combined length of the four remaining segments, fifth tarsal segments with two ventral rows of blunt tipped spines; tarsal claws long and equal, each possessing a large basal tooth. Wings hyaline, anterior veins light yellow, vein $\left(R_{1}\right)$ terminating at costa before $\left(R_{3}\right)$, vein $\left(R_{4+5}\right)$ 
joining costa at a point six sevenths of the distance from wing base to apex, cubitus forking just beyond the crossvein; anal vein forked, the anterior branch joining the tip of vein $\left(\mathrm{Cu}_{2}\right)$ at the wing margin, posterior branch short and sinuous.

Male.-Undescribed.

Length. $-3.00 \mathrm{~mm}$.

Coll. by Nathan Banks, Soledad, Cienfuegos, Cuba. June.

This species will run to B. setipes Coquillett in Malloch's key for the genus Bezzia. Since, however, B. setipes possesses yellow fore and mid tibiæ and the number and arrangement of the femoral spines differ in the two species, they may be readily separated.

Tanypus brooksi, sp. nov.

Male.-Brownish yellow. Head yellow; antennæ light brown, longer than head and thorax combined, scape dark brown with greenish pruinescence, palpi yellow. Thorax light brown, pronotum with silvery sheen, mesonotum with dark ground color nearly obscured by heavy greenish pruinescence, pleurae pale brown with slight pruinescence, scutellum yellowish, postnotum blackish brown with greenish pruinescence, halters yellow with blackish knob. Abdomen yellow, segments three to seven yellow with brown basal bands, segments seven and eight black with conspicuous whorls of long coarse blackish hairs, venter yellow. Legs pale brown, clothed with short brownish hairs; femora pale brown, tibiae yellowish, the apices narrowly brown; tarsi pale yellow, the apices of segments one, two and three narrowly brown; fourth and fifth segments entirely brown, ratio between fore tibiae and fore metatarsi (14-9). Wings whitish, unspotted, sparsely clothed with short brownish hairs, veins nearly colorless, costa terminating in front of apex, vein $\left(R_{1}\right)$ at a point two-fifths the distance from crossvein to end of costa, vein $\left(R_{4+5}\right)$ terminating at a point three-fifths the distance from crossvein to tip of costa, crossvein not infuscated. Hypopygium yellow, coxites long and blunt; styli narrow, resembling those of T. illinoensis but possessing a simple tip as in T. hirtipennis. 
Female.-Undescribed.

Length. - 2.50 to $3.00 \mathrm{~mm}$.

Coll. by W. S. Brooks, Moneague, Jamaica. January.

The outstanding characteristics of this species are as follows:-heavy greenish pruinescence of mesonotum and silvery pruinescence of pronotum; brown basal bands of abdominal segments three, four, five and six; the blackish seventh and eighth abdominal segments with whorls of long, black, spine-like hairs; conspicuous yellow coxites of the hypopygium.

Chironomus jamaicensis sp. nov.

Male.-Yellowish green. Head yellow, antennæ brown, scape brown, palpi yellowish brown. Thorax yellow, mesonotum yellow with wide reddish vittae, pleurae yellowish, scutellum pale greenish yellow, postnotum brown; halters pale yellow to white, the apex slightly greenish. Abdomen yellow, the first three basal segments often greenish, remaining segments including the hypopygium pale brown, venter greenish yellow. Legs yellow, mid and hind legs sparsely clothed with long brownish hairs, coxae yellowish, fore femora dark brown, mid and hind femora greenish yellow; fore tibiae brownish, the apices narrowly blackened, apical comb absent; mid and hind tibiae yellowish with conspicuous black apical combs; fore tarsi entirely brown, metatarsi nearly twice as long as fore tibiae, ratio between fore tibia and tarsal segments as follows 40 $70,40,30,25,15$; mid and hind tarsi brownish yellow, the distal half of second and the entire third, fourth and fifth segments blackened. Wings hyaline, veins pale yellow, crossvein not infuscated, vein $\left(R_{1}\right)$ joining the costa at a point slightly more than half the distance from crossvein to tip of vein $\left(R_{4+5}\right)$, media and $\left(R_{4+5}\right)$ equidistant from wing apex, cubitus forking distinctly beyond crossvein. Hypopygium similar to that of $C$. decorus.

Female.-Agrees with male regarding color.

Length.-3.50 to $4.00 \mathrm{~mm}$.

Coll. by W. S. Brooks, Moneague, Jamaica. February. 
This species appears to be closely related to $C$. decorus and $C$. serus from the standpoint of male hypopygium, but differs from these in regard to abdominal markings, the absence of any discernible infuscation of the crossvein, and also in the fork of the cubitus which is located beyond the crossvein.

\section{Chironomus bulbosa sp. nov.}

Male.-Yellow, marked with green. Head greenish yellow, antennæ brown, plume whitish at base, scape pale brown. Thorax greenish with reddish vittæ, scutellum green, postnotum yellow, halters white with greenish apices. Abdomen greenish yellow, sparsely clothed with short yellow hairs. Legs pale green; fore femora and fore tibiæ light brown, narrowly blackened at apices; fore metatarsus less than one and one-half times length of fore tibia (10-13) ; mid and hind femora and tibiæ greenish yellow, densely clothed with long yellowish hairs; tarsi pale brown, the fourth and fifth segments blackened. Wings hyaline, greenish at base, veins pale brown, vein $\left(R_{4+5}\right)$ and media equidistant from wing apex; cubitus forking beyond the crossvein. Hypopygium brownish yellow; the coxites and inner processes large, curved and leaf-like, forming a conspicuous bulb at tip of abdomen.

Female.-Differs slightly in coloration, i.e., the head, greater portion of thorax, and the abdomen are a deeper green.

Length.-3.00 to $3.50 \mathrm{~mm}$.

Coll. by Nathan Banks, Soledad, Cienfuegos, Cuba. August.

The male of this species may be easily identified by the bulbose form of the hypopygium. 

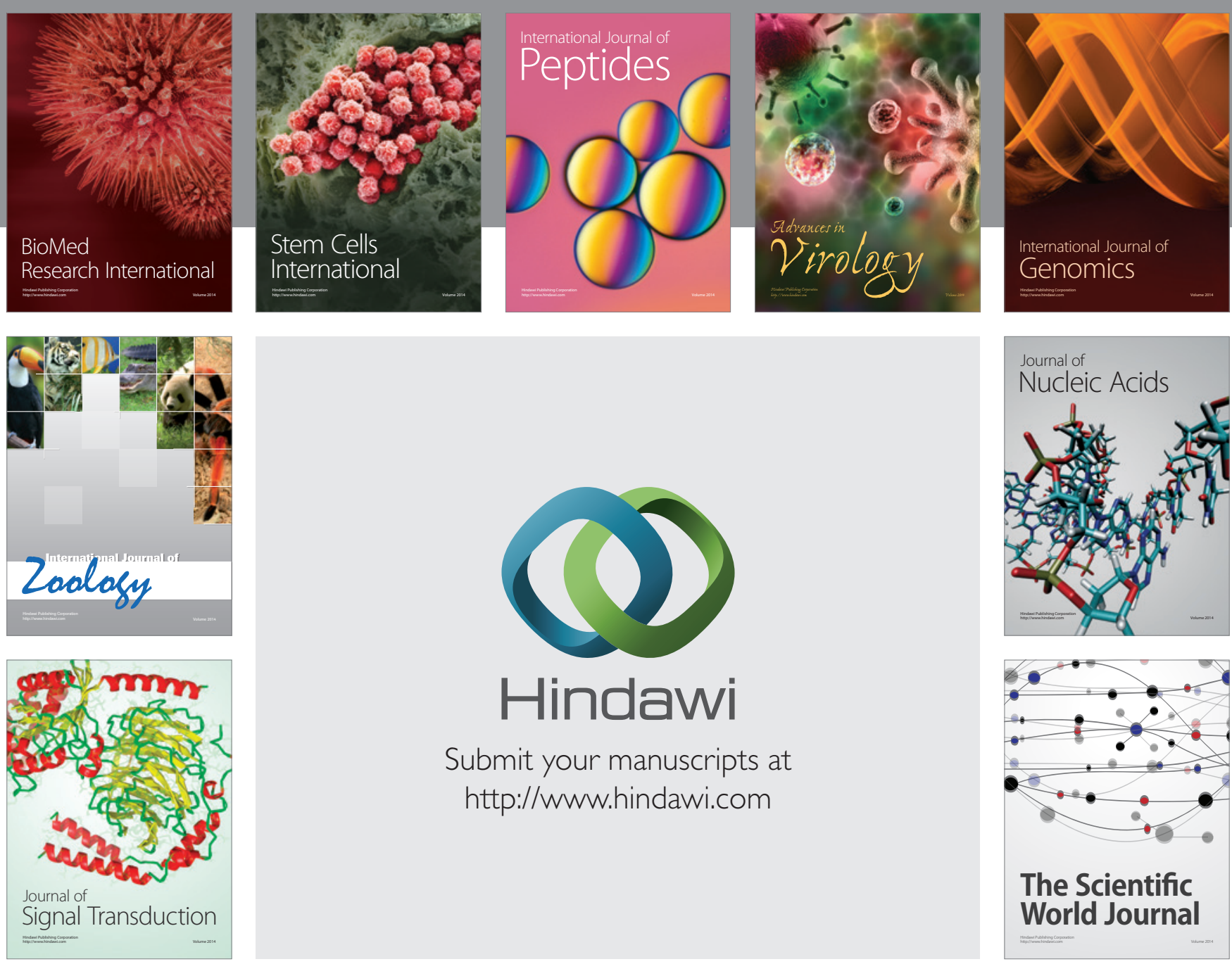

Submit your manuscripts at

http://www.hindawi.com
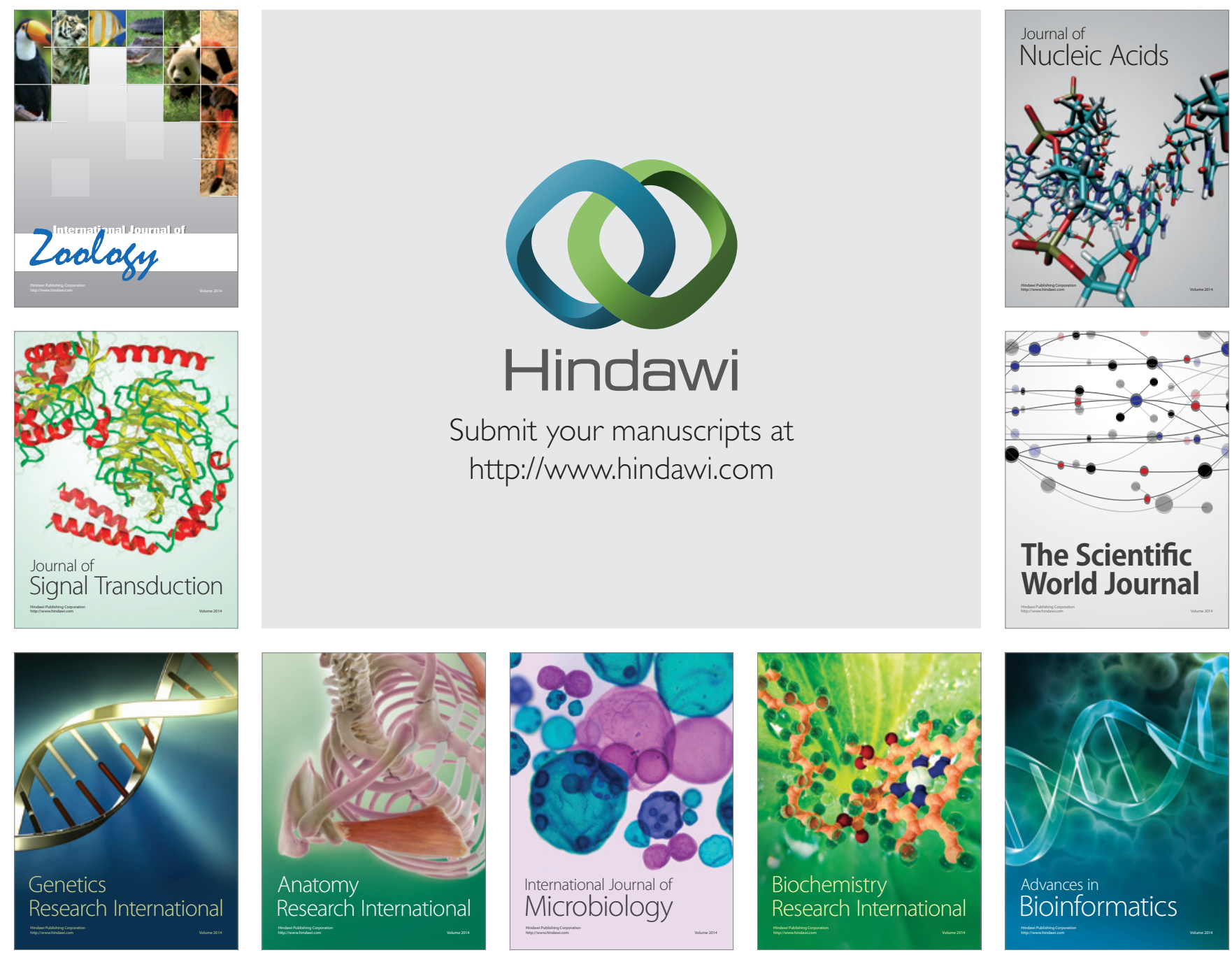

The Scientific World Journal
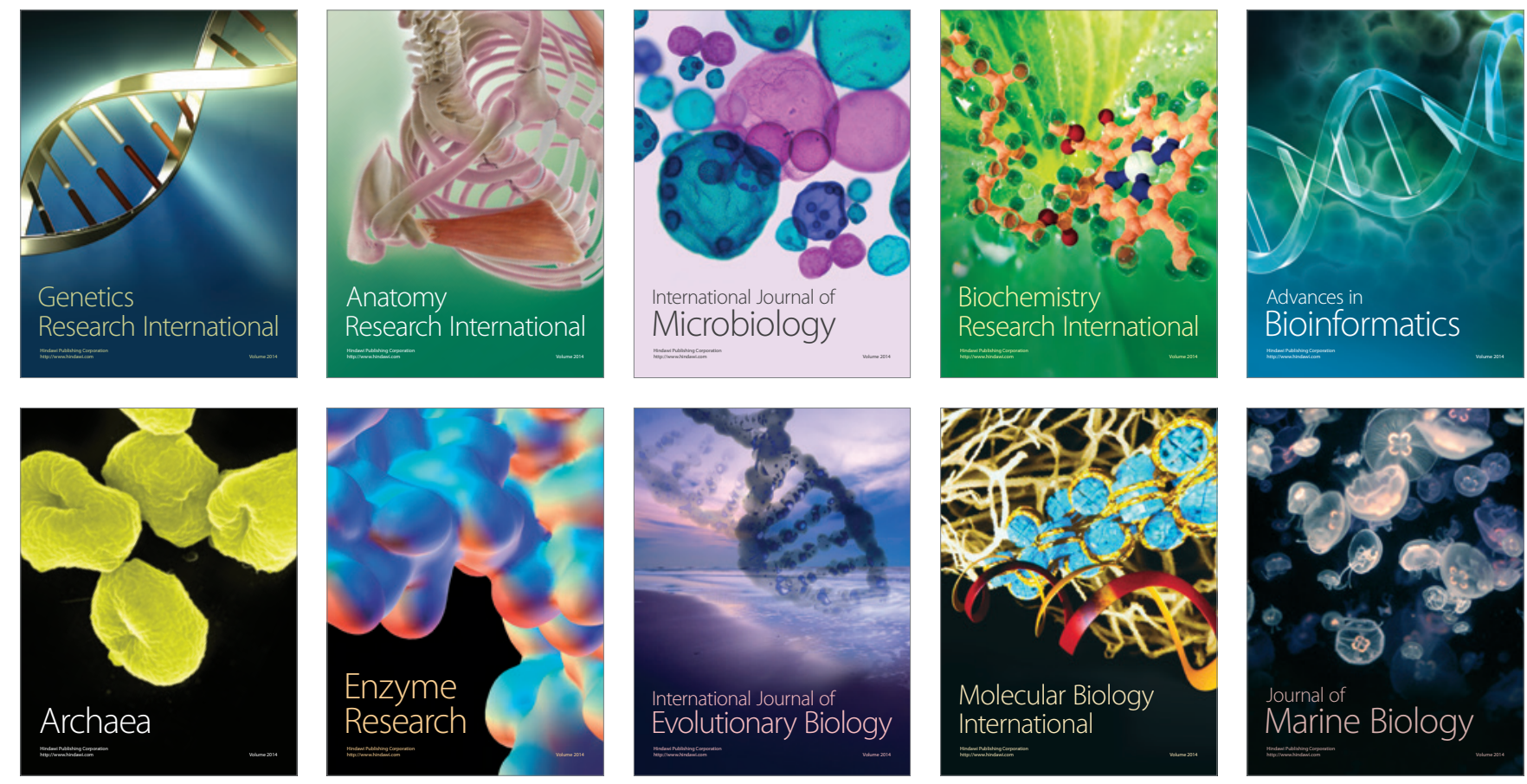